\title{
GUSB wt Allele
}

National Cancer Institute

\section{Source}

National Cancer Institute. GUSB wt Allele. NCI Thesaurus. Code C148005.

Human GUSB wild-type allele is located in the vicinity of $7 q 11.21$ and is approximately 22

$\mathrm{kb}$ in length. This allele, which encodes beta-glucuronidase protein, plays a role in the

metabolism of glycosaminoglycans. Mutation of the gene is associated with

mucopolysaccharidosis VII. 